\section{Physicist convicted over links with Iran and China}

On 3 September, a federal jury found electrical engineer J. Reece Roth, 70, guilty on 17 counts for conspiracy, wire fraud and violating the Arms Export Control Act. Roth, a professor emeritus at the University of Tennessee in Knoxville, had been working on ways of using plasma to reduce drag on aircraft wings.

He had employed both Chinese and Iranian graduate students without proper authorization (see Nature 442, 232; 2006). Roth will be sentenced on 7 January 2009;

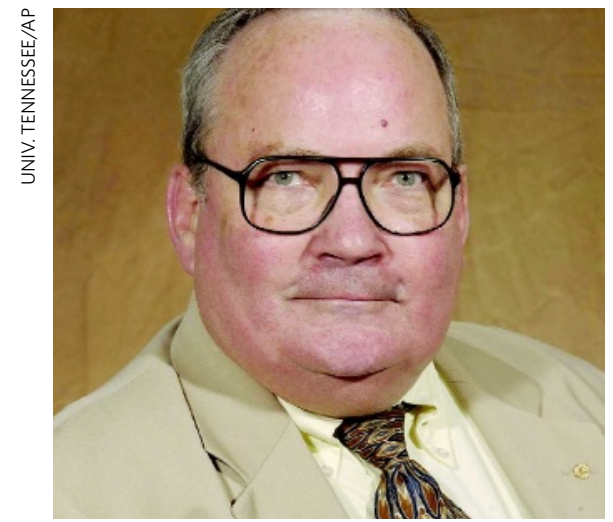

J. Reece Roth he faces a maximum sentence of 150 years.

The conviction serves as a warning to other academics, says Russ Dedrick, a US attorney with the Eastern District of Tennessee. "Our scientific and educational communities must take precautions to ensure that technology and research are protected," he says.

\section{Lancet retracts paper on stem-cell treatment}

The medical journal The Lancet retracted an article by urologists at the Medical University of Innsbruck in Austria last week (S. Kleinert and R. Horton Lancet 372, 789-790; 2008).

The article claimed positive results for a clinical trial using stem cells to treat urinary incontinence, but this summer an investigation by the Austrian government's Agency for Health and Food Safety found serious flaws in the trial, including incomplete patient consent forms and forged insurance documents (see Nature 454, 922-923; 2008). An Austrian Academy of Sciences investigation continues. The university suspended principal investigator Hannes Strasser, but took no sanctions against department head, Georg Bartsch, who was an honorary co-author on the paper. Both have denied wrongdoing. A Lancet editorial accompanying the retraction decried honorary authorships as "unacceptable" and said that such authors still have obligations in cases of flawed research: "With credit comes responsibility - always."

\section{India wins waiver to buy nuclear technology}

After three days of deliberation in Vienna, the 45-member Nuclear Suppliers Group (NSG), which regulates global nuclear trade, has bent its rules to allow India to trade with member countries in order to expand Indian civilian nuclear operations.

India has been barred from trading since it first tested nuclear weapons in 1974. The NSG's decision was the result of intense lobbying by the United States - which has a landmark agreement with India pending congressional approval - and support from France and Russia.

The NSG waiver follows a similar endorsement from the International Atomic Energy Agency in July. These actions stand to grant India access to nuclear fuel and technology for energy without its having to sign a non-proliferation agreement. The Communist Party of India called for the Indo-US nuclear deal to be quashed, saying it infringes India's sovereignty. 